\title{
The production and use of human capital: Introduction
}

Citation for published version (APA):

Borghans, L., \& Heijke, J. A. M. (2005). The production and use of human capital: Introduction. Education Economics, 13(2), 133-142. https://doi.org/10.1080/09645290500031033

Document status and date:

Published: 01/01/2005

DOI:

10.1080/09645290500031033

Document Version:

Publisher's PDF, also known as Version of record

\section{Please check the document version of this publication:}

- A submitted manuscript is the version of the article upon submission and before peer-review. There can be important differences between the submitted version and the official published version of record.

People interested in the research are advised to contact the author for the final version of the publication, or visit the DOI to the publisher's website.

- The final author version and the galley proof are versions of the publication after peer review.

- The final published version features the final layout of the paper including the volume, issue and page numbers.

Link to publication

\footnotetext{
General rights rights.

- You may freely distribute the URL identifying the publication in the public portal. please follow below link for the End User Agreement:

www.umlib.nl/taverne-license

Take down policy

If you believe that this document breaches copyright please contact us at:

repository@maastrichtuniversity.nl

providing details and we will investigate your claim.
}

Copyright and moral rights for the publications made accessible in the public portal are retained by the authors and/or other copyright owners and it is a condition of accessing publications that users recognise and abide by the legal requirements associated with these

- Users may download and print one copy of any publication from the public portal for the purpose of private study or research.

- You may not further distribute the material or use it for any profit-making activity or commercial gain

If the publication is distributed under the terms of Article $25 \mathrm{fa}$ of the Dutch Copyright Act, indicated by the "Taverne" license above, 


\title{
The Production and Use of Human Capital: Introduction
}

\author{
LEX BORGHANS and HANS HEIJKE \\ Research Centre for Education and the Labour Market, Maastricht University, The Netherlands
}

\begin{abstract}
With the growing importance of knowledge, new research questions arise that require more explicit analyses of the way human capital is produced and how it is used in the labour market. In this introduction to this special issue we provide examples of such questions and argue that economics can play an important role in areas traditionally studied by educationalist solely. From this perspective we summarize the six contributions in this special issue.
\end{abstract}

KEY WORDS: Human capital; skills; learning, economics of education

\section{Heterogeneous Human Capital}

In his Presidential Address in 1960 to the American Economic Association, Theodore Schultz (1961) explained in masterly fashion the principle of investing in people in order to increase their job opportunities. Obvious examples of investments in human capital include education, health improvements and migration. Education may provide people with skills and knowledge that can be used for being productive in the labour market. There are various ways to achieve this. After leaving the education system, people may increase the skills and knowledge that they have acquired by practising their professions and by additional training. Not all learning routes are equally effective for producing certain types of skills and knowledge. Schools can be organized in very different ways, and didactical approaches might differ substantially in their impact.

Assuming perfect knowledge about how people learn and what is valuable in the labour market, such considerations about what happens in the classroom and how people learn on the job are not relevant for economic analyses. Becker (1964) shows that when people choose the investments that have the highest returns, human capital-measured by the earnings it can generate-depends solely on the inputs in the learning process, measured either in monetary terms or in time spent on education. Although both education and labour economics on the one hand and educational science on the other hand, study education and training, they do so quite independently. The assumption of optimal investment behaviour creates a dichotomy between both disciplines, in which educationalists are searching for the

Correspondence Address: Lex Borghans, Research Centre for Education and the Labour Market (ROA), Maastricht University, PO Box 616, 6200 MD, Maastricht, The Netherlands. Email: 1.borghans@roa.unimaas.nl 
best way to teach people, and economists only need to know the benefits of an additional year of schooling or an increase in the school budget, to investigate whether marginal investments in education are in balance with the returns to education. Knowledge about the social and private return to education provides sufficient information to answer the question of what would be the optimal investment in education, and what share the government should take in this investment.

To estimate the return on investment in human capital through learning processes such as education, training and experience, use is often made of the Mincerian approach (Mincer, 1974). This approach links income from work to the human capital acquired through these learning processes, expressed as the number of years spent in a particular learning environment. Account may be taken of the regular updating of knowledge in education, by expressing study years in vintages (Neuman and Weiss, 1995). The gradual obsolescence of knowledge and skills may be addressed by applying a system of depreciation to the human capital acquired (Rosen, 1975). To answer the questions of whether investments in education are sufficiently large and to what extent the government should subsidize education, empirical work has put much emphasis on measuring the true return to education, acknowledging that people will differ in their ability to learn. These differences will affect both the size of the optimal investment and its returns, creating an endogeneity problem in the measurement of the return to education, asking for creative statistical solutions.

There are, however, many economic questions that remain unanswered by this approach. Important economic questions are not only how large investments in education should be, but also: (1) what kind of skills school should focus on taking into account the complexity of the labour market; (2) what is the best way for people to acquire these skills; and (3) how can we create institutions that create the right incentives for students, parents and teachers to optimize achievement? Fundamental to these questions is that the assumption of optimal investment behaviour has to be put aside. Unobserved heterogeneity of student ability is not the only form of heterogeneity that matters in education. Our claim is that to investigate such issues the dichotomy between economics and educational science has to be abolished. Economic analyses are needed in which the learning process and the way people utilize their skills in their work is made explicit.

This special issue of Education Economics brings together six papers in which the production and use of human capital is explicitly taken into account. They have been presented at the annual human capital workshop in Maastricht in 2003. In the next section of this introduction we further explain why for many important questions regarding education, economic considerations cannot be isolated from more detailed considerations about the way people learn and the way people use their skills in the workplace. In the third section we will discuss the contributions in this issue from this perspective, and we end the introduction with some conclusions.

\section{Investigating the Production and Use of Human Capital}

A first important economic question regarding what should be learned at school refers to the types of skills that are important in the labour market. Becker (1962) distinguishes two types of human capital: firm-specific human capital and general human capital. Firm-specific human capital can only be used in the firm in which it was acquired, while general human capital can be transferred to other firms. In a competitive labour market, firms will only take care of the training that 
provides firm-specific skills. Employees will need to pay for the costs of any general training themselves, because the resulting returns will be compensated in full by the market wages that need to be paid to those who have completed such training. Assuming that people acquire those skills that have the highest returns in the labour market, there is no need to know the nature of these skills. It is only their tradeability that matters.

Requirements in the labour market are very diverse and constantly changing. It is therefore unlikely that all people involved know exactly the labour market value of different skills. Hartog (1992) distinguishes a multiple set of skills. The confrontation between the skills supplied in the labour market and the skills demanded for the jobs results in wages that include shadow prices for skills. There is ample evidence that skill requirements have been changing in recent decades. Murnane et al. (1995) report a growing importance of cognitive skills, and Gould (2002) finds an increasing importance of general skills in the USA. Autor et al. (2003) show that the computerization of the labour market changed the demand for skills.

Apart from changes in the value of skills, there are also more intrinsic tradeoffs in the curriculum to be made. The distinction between academic and vocational skills received much attention in this respect. Bishop (1995) concludes, based on a comparison of the courses student take at high school, 'that for most jobs productivity derives directly from social abilities (such as good work habits and people skills) and cognitive skills that are specific to the job and occupation: not from reading, writing and mathematics skills'. He further states that reading and mathematics skills have only an indirect effect on productivity, because these academic skills help the individual to learn the occupation-specific and jobspecific skills. Heijke et al. (2003) have drawn similar conclusions from research among graduates from higher education. Vocational skills obtained in education make individuals directly productive if they find jobs within the domain of their studies, while generic skills are important for the adaptation to an occupation outside that domain and the acquisition of any new skills required for innovations within the occupation or for any further career steps. The importance of learning different types of skills at school therefore depends on uncertainty in the labour market, and the way people can adjust to changing circumstances fading out the distinction between educational and economic questions.

Second, people can learn at school but also at work. This also leads to economic questions with respect to the curriculum. An interesting example relates to the increased importance of computer at work (Green and Dickerson, 2004). A logical response to this change is to pay more attention to computer skills in the classroom. Borghans and ter Weel (2004), however, find no significant relationship between computer skills and wages. A possible explanation for this finding is that computer skills are easily obtained while working. If it is much easier to learn how to use a computer by doing, learning these skills at school possibly only substitutes for what would be learned later anyhow. Learning these skills at school could go at the costs of other skills, while learning at work might go together with productive labour. The decision what to include in a school curriculum therefore depends not only on the value of skills and the costs to produce them, but also on later opportunities to acquire the same skills, again making an explicit integration of economic and educational analyses necessary. Lessons can be structured in such a way that people learn several skills simultaneously. Also, at work learning and production can go hand in hand. These forms of joint production may complicate the analyses of the curriculum. 
A second important economic question refers to what is the best way for people to acquire skills. Either assuming that given the time and budget available teachers and students optimally use the resources to learn as much as possible, or assuming that policy can only affect these inputs and not the way they are used, in research on the return on investment in human capital, the education process usually remains a black box. Some specific themes, however, attracted attention from economists. There is a very large economic literature on class size effects (Angrist and Lavy, 1999; Dobbelsteen et al., 2002; Krueger, 1999; Wößmann and West, 2002). Based on natural experiments other educational interventions have also been investigated such as teacher training (Angrist and Lavy, 2001), school hours (Lavy, 1999a; Leuven et al., 2004a), and additional funding (Leuven et al., 2004b). Angrist and Lavy (2002) and Leuven et al. (2004b) investigate the effect of ICT on student achievement. Opening this box in fact means studying the production function of education (for example, Card and Krueger, 1992; for an overview, we refer to Hanushek, 1986, 1997). The function describes the educational attainment of pupils as a function of their individual characteristics and abilities, the contribution received from their families, the quality inputs from school, and the quality inputs from their teachers.

Theoretical studies of these educational interventions show that also within a class economic considerations play an important role to explain the effects of inputs on performance. Lazear (2001) shows that many of the empirical findings regarding class size can be understood by taking into account the negative effect on the performance of others in the classroom when individual students require individual attention of the teacher. Borghans (2003) and Rice (1999) add to this that also the behaviour of a teacher might depend on the circumstances. There is not just one didactic method for achieving a particular educational attainment in pupils. Education may be more teacher-centred or more student-centred, and the learning environment may be less or more activating for pupils. Institutions may also have an effect on educational attainment. There may be regulations with regard to the level of the available budget, the final attainment levels to be reached, the method of examination, the selection of pupils, the didactic method to be used, and the degree to which the school is able to pursue an autonomous policy with regard to these aspects. In empirical work there still seems to be some hesitance to go beyond measuring the effects of changes in the inputs and also investigate the effects of the way teachers use available resources. Recently, Machin and McNally (2004) showed that the introduction of the Literacy hour in Britain did substantially improve achievement. The literacy hour changed the way literacy is taught without increasing the available budget. Their findings therefore provide clear evidence that actual teaching practices can be far from optimal, and consequently economic analyses of the efficiency of teaching methods can be very useful.

Also in the study of peer effects in education (Hanushek et al., 2003; Hoxby, 2000; Lavy, 1999b; Sacerdote, 2001), economic mechanisms play an important role. There is ample evidence that the achievement of students depends strongly on their peers. The theoretical implications that under these circumstances the achievement of students depends on the study behaviour of others (not only their characteristics and socio-economic background) and that this could lead to discrepancies between what is optimal for the individual and what is optimal for the group have not yet been analysed. 
Even if one were to have information on all these decisive factors of educational attainment, then it would still not be easy to estimate their impact on pupils. For example, the production function concept takes no account of the fact that the inputs concern actors who may have their own interests, which may not always correspond to those of their pupils. If one fails to pay attention to such interests, regulations affecting the funding of courses and the wages of teachers may trigger unintended reactions in schools and teachers, which ultimately affect the optimal learning results for certain groups of pupils.

These examples show that many questions about the way people acquire and use skills human capital have clear economic aspects. Traditionally, however, they are the field of educational science solely. We think by taking a more explicit look at how people learn and how they use their skills, economics can provide a very useful contribution to these questions. ${ }^{1}$

\section{The Contributions}

This special issue contains six papers, each of which focuses on certain facets of the problems already outlined. Ludger Wößmann studies the heterogeneity of the effects of external exit examinations on student performance. He investigates whether these effects vary according to student ability, parental background, the degree of school autonomy and the grade in which the central exit examinations are implemented. John Bishop and Ferran Mane investigate the impact of tougher graduation requirements on course-taking patterns, college attendance and completion, and post-high school labour market outcomes. They try to find out whether there are any differences between vocational concentrators and nonconcentrators. Othman Joumady and Catherine Ris study the differences in efficiency between institutions of higher education. They try to determine to what extent individual institutions are able to provide vocational and generic competencies to graduates and to match these competencies to the competencies required in the job. Jasper van Loo and Bert Toolsema have developed a methodology for identifying key skills. They investigate whether these key skills indeed have a major impact on productivity. Ben Kriechel and Gerard Pfann study experienced unemployment duration and wage losses of former employees of a large firm that went bankrupt. They have investigated the impact of the general human capital present in these employees and the specific human capital accumulated in the firm. Peter Dolton, Gerald Makepeace and Oscar Marcenaro have studied the relative positions of individuals within a cohort over a very long period of time. They have made links between their relative positions as children in the education system and their relative positions as adults, in terms of their earnings.

The theoretical background of Ludger Wößmann's paper is that information may provide incentives and influence behaviour. The extent of the effect of central examinations on the performance of students is not a purely educational issue, but is partly determined by the behaviour of parties involved, who react to incentives. For example, the positive incentive effect of central examinations may be smaller for low-ability students than for high-ability students, because the central examination sends an inter-regionally assessable signal to employers, which has a more favourable effect for high-ability students, who are more mobile. Considering the fact that parents may exert pressure on both students and teachers, it may be expected that the effects of central examinations will be greater if parents take a great interest in their children's progress at school. The 
impact of school on student performance in the case of central examination depends on whether a school has superior local knowledge and acts in an opportunistic way. If a school has incentives to behave in an opportunistic way, for example, and also has a local knowledge lead, then the central examinations will have a positive impact on the performance of its students. Wößmann investigated these possible effects using various international databases containing test results of students in the seventh and eighth grades with regard to their skills in mathematics, science and reading. The data came from two Third International Mathematics and Science Study (TIMSS) studies and the Programme for International Student Assessment (PISA). Most international tests did indeed show that the positive effects of central examination were greater for high-ability students. However, the test results do not vary substantially along most family background dimensions. The effect of central examinations is also much greater for schools that have autonomy with regard to the various decision fields. Favourable effects of central examinations on student achievement in the course of their school careers were also found.

The contribution by John Bishop and Ferran Mane also has as its theoretical background that information may provide incentives and may have an effect on the behaviour of the parties involved. The introduction of a minimum competency examination in education, for example, may have a signalling effect for subsequent education and for employers, as students can now be labelled as either a passer or a failer. This makes it easier for subsequent education to select the best students and for employers to choose the right employees, who will also earn higher wages. It will also have a learning effect, as the simpler accountability of their performance will encourage teachers and administrators to make a greater effort and students to work harder. Bishop and Mane investigated the effects of three different policies that may have been introduced in the high school system of various states in the United States. These policies are state-defined minimums for the total number of courses students must take and pass to obtain a high school diploma, state-defined minimums for the number of academic courses necessary to obtain a diploma, and minimum competency graduation tests. The underlying idea behind these measures is that high school students are forced to strengthen their background in academic subjects. Greater skills in reading, writing, mathematics and science are presumed necessary to deal successfully with changes in technological developments, management innovations and global competition. The study made use of micro-data from the National Educational Longitudinal Study (NELS-88). One of the findings were that increasing the number of academic courses necessary to graduate results in higher wages and earnings, both immediately after graduation and seven years later. However, higher academic course requirements do not improve college attendance and completion rates, and vocational concentrators are less likely to obtain an associate's or bachelor's degree. One of the conclusions is therefore that tough academic course requirements and minimum competency examinations lead to an enhanced reputation of vocational concentrators among employers, which increases their marketability.

The theoretical framework of the contribution by Othman Joumady and Catherine Ris consists of the production function of educational institutes; in particular, the efficiency with which such institutes transform inputs into outputs. Using a non-parametric method (Data Envelopment Analysis), they have evaluated the relative performance of universities and other higher educa- 
tion institutions in their capacity to prepare graduates for their transition to the labour market. Two aspects are concerned: universities' capacities to provide vocational and generic competencies, and to adjust these competencies to labour market requirements. Joumady and Ris applied their model to a large sample of young graduates from 209 higher education institutions across eight European countries. The authors report substantial differences in efficiency between institutions and between countries. They suggest that the efficiency differences between countries that they found reflect the differences between these countries in the degree to which the costs of education are shifted from the higher education system to the early working career stage, in the sense of further learning needed.

The paper by Jasper van Loo and Bert Toolsema ties in with the scholarly debate on key skills. These are often regarded as skills that can be used productively in various work-related contexts, independent of specific tasks performed. The literature deals extensively with a definition and the question of which skills must be regarded as key skills. Van Loo and Toolsema believe that in contrast to the subtle discussion about the concept of key skills, the choice of which skills actually are key skills is merely determined by ad hoc lists of what skills employers regard as important. In this paper, they want to show that it is possible to develop an empirical criterion for the identification of key skills on the basis of a theoretically sound definition of key skills. Using data from a survey of Dutch intermediate vocational education graduates, van Loo and Toolsema identified the key skills for this group. To do so, they used the answers given by respondents to the question to what extent 15 different skills were required in their jobs. Deciding on which skills are key skills is done in two steps. To find the indirect skills effects, each skill is first regressed to all other skills. Then a hedonic wage equation is estimated for each skill, in which the skill concerned and the sum total of all other skills are related to log wages. These estimates are used to derive what can be regarded as key skills: problem-solving skills, independence, oral presentation/speaking skills, accuracy/carefulness, and initiative/creativity. The greatest indirect contribution to wages is provided by the key skills independence, accuracy/carefulness, and initiative/creativity.

The contribution by Ben Kriechel and Gerard Pfann deals with the question to what extent the human capital of a firm is transferable. Tenure is often used as a proxy for the human capital accumulated in a firm, which is lost when an employee leaves. Nevertheless, studies have shown that a part of the human capital accumulated in this way is actually transferable. To determine the transferability of human capital, the literature lists displacement studies that have been carried out in which the post-displacement search time and the pre-displacement and post-displacement earnings among workers have been investigated. The advantage of studying displaced workers instead of regular lay-offs is that the former are not specifically selected into unemployment, but constitute part of a firm that closed down. They made use of data on permanently displaced workers from a Dutch aircraft company that went bankrupt in 1997. There is detailed information about the workers in the firm, just before the displacement that could proxy human capital. On the basis of their analyses of the duration of unemployment after displacement and the level of wage loss incurred, the authors concluded that the classification of workers into fields of work that are more or less specific is a far better predictor of wage losses than the indicator of accumulated specific human capital tenure within the displacing firm, which is often used in the literature. In addition to the 
commonly used variable of education as an indicator of general human capital, they suggested adding the hierarchical position of a worker as a variable, because this may have a strongly negative effect both on the duration of unemployment and on wage loss. These results show that the skills people acquire at work, and whether these skills are general or specific, depends not only on educational background and years of education, but is also related to the character of the experience these workers have had.

Peter Dolton, Gerald Makepeace and Oscar Marcenaro mention the typically economic approach to investigating career progress in terms of investments in human capital and the resulting impact across the lifecycle on earnings. The starting point of a career in the labour market is the human capital accumulated in initial education. Further career progress is determined by any on-the-job training. The extent achieved and further growth of human capital is always the result of individual optimization decisions, based on objectives to be reached and constraints present, such as personal ability and access to sources of funding. Economists usually estimate this lifecycle model by means of cross-sectional data of individuals at different stages in their lives. Dolton, Makepeace and Marcenaro, however, have made use of data on a cohort of people and examined movements within that cohort. They derived their data from the British National Child Development Study (NCDS), in which individuals who were born in a particular week were interviewed at various stages of their lives. For the paper, they made use of data at the ages of 11, 16, 33 and 42 . The data from the 11 year olds and 16 year olds consist of early test scores and public examination success in education, respectively, while those from the 33 year olds and 42 year olds concern occupational earnings in the labour market. When estimating the changes in occupational earnings between the ages of 33 and 42 they found that upward shifts in the earnings distribution were conditioned by early ability, educational attainment, and labour market experience. These findings therefore suggest that education not only plays a role in the formation a human capital directly, but also provides students with skills that help them to acquire human capital more easily later on in their career.

\section{Conclusion}

Although educational science and economics have intensively investigated education and learning in general, traditionally there has been a dichotomy in which educationalists focused on the question of how to improve the way people learn, while economists took the efficiency of the production process for given and focused on the optimal amount of investments in human capital.

Our claim is that with the growing importance of knowledge in the society, the increased uncertainty in the labour market and the more complicated ways in which people acquire skills, both at school and in the workplace, requires economists to investigate the production and use of human capital more explicitly. Many questions that at first sight appear to be purely educational, turn out to have important economic aspects.

The papers in this special issue provide very interesting examples of such economic studies. We believe that in the future economics will further contribute to the understanding of the production and use of human capital. The collection of adequate data will of course be important to continue this line of research. 


\section{Acknowledgement}

\section{Financial support from the Dutch National Science Foundation is gratefully acknowledged.}

\section{Note}

1. This also affects the data that need to be collected for economic analyses (see Borghans et al., 2001).

\section{References}

Angrist, J. and Lavy, V. (1999) Using Maimonides' rule to estimate the effect of class size on scholastic achievement, Quarterly Journal of Economics, 114, pp. 533-575.

Angrist, J. and Lavy, V. (2001) Does teacher training affect pupil learning? Evidence from matched comparisons in Jerusalem public schools, Journal of Labor Economics, 19, pp. 343-369.

Angrist, J. and Lavy, V. (2002) New evidence on classroom computers and pupil learning, Economic Journal, 112, pp. 735-765.

Autor, D. H. et al. (2003) The skill content of recent technological change: an empirical exploration, Quarterly Journal of Economics, 118(4), pp. 1279-1333.

Becker, G. (1962) Investment in human capital: a theoretical approach, Journal of Political Economy, 70(5), Part 2, pp. 9-49.

Becker, G. (1964) Human Capital: A Theoretical and Empirical Analysis with Special Reference to Education (New York, NBER).

Bishop, J. H. (1995) Vocational education and at risk youth in the United States, Vocational Training, 6, pp. 34-42.

Borghans, L. (2003) Class teaching and individual instruction. Mimeo (ROA: Maastricht).

Borghans, L. and ter Weel, B. (2004) Are computer skills the new basic skills? The returns to computer, writing and math skills in Britain, Labour Economics, 11(1), pp. 85-98.

Borghans, L. et al. (2001) Skills measurement and economic analyses: an introduction, Oxford Economic Papers, 53(3), pp. 375-384.

Card, D. and Krueger, A. (1992) Does school quality matter? Returns to education and the characteristics of public schools in the United States, Journal of Political Economy, 100, pp. 1-40.

Dobbelsteen, S. et al. (2002) The causal effect of class size on scholastic achievement: distinguishing the pure class size effect from the effect of changes in class composition, Oxford Bulletin of Economics and Statistics, 64, pp. 17-38.

Gould, E. D. (2002) Rising wage inequality, comparative advantage, and the growing importance of general skills in the United States, Journal of Labor Economics, 20(1), pp. 105-147.

Green, F. and Dickerson, A. (2004) The growth and valuation of computing and other generic skills, Oxford Economic Papers, 56(3), pp. 371-406.

Hanushek, E. (1986) The economics of schooling: production and efficiency in public schools, Journal of Economic Literature, 24, pp. 1141-1177.

Hanushek, E. (1997) Assessing the effects of school resources on student performance: an update, Educational Evaluation and Policy Research, 19, pp. 141-164.

Hanushek, E. et al. (2003) Does peer ability affect student achievement?, Journal of Applied Econometrics, 18 , pp. 527-544.

Hartog, J. (1992) Capabilities, Allocation and Earnings (Dordrecht: Kluwer Academic Publishers).

Heijke, H. et al. (2003) Fitting to the job: the role of generic and vocational competencies in adjustment and performance, Labour Economics, 10(2), pp. 215-229.

Hoxby, C. (2000) Peer effects in the class room: learning from gender and race variation. NBER working paper 7867 (Cambridge, MA: NBER).

Krueger, A. (1999) Experimental estimates of educational production functions, Quarterly Journal of Economics, 114, pp. 497-532.

Lavy, V. (1999a) Externalities and efficiency effects of class heterogeneity on student scholastic achievement. Mimeo (Jerusalem: Hebrew University).

Lavy, V. (1999b) Using dual natural quasi-experiments designs to evaluate the effects of school hours and class size on student achievement. Mimeo (Jerusalem: Hebrew University).

Lazear, E. (2001) Educational production, Quarterly Journal of Economics, 116, pp. 777-803.

Leuven, E. et al. (2004a) The effect of potential time in school on early test scores. Mimeo (Jerusalem: Amsterdam). 
Leuven, E. et al. (2004b) The effect of extra funding for disadvantaged pupils on achievement. Mimeo (Amsterdam).

Machin, S. and McNally, S. (2004) The literacy hour. Mimeo (London: LSE).

Mincer, J. (1974) Schooling, Experience and Earnings (New York: Columbia University Press).

Murnane, R. J. et al. (1995) The growing importance of cognitive skills in wage determination, Review of Economics and Statistics, 77(1), pp. 251-266.

Neuman, S. and Weiss, A. (1995) On the effects of schooling vintage on experience-earnings profiles: theory and evidence, European Economic Review, 39(5), pp. 943-955.

Rice, J. (1999) The impact of class size on instructional strategies and the use of time in high school mathematics and science courses, Educational Evaluation and Policy Analyses, 21, pp. 215-230.

Rosen, S. (1975) Measuring the obsolescence of knowledge, in: F.T. Juster (Ed) Education, Income and Human Behaviour, pp. 199-232 (New York: Carnegie Foundation for the Advancement of Teaching and National Bureau of Economic Research).

Sacerdote, B. (2001) Peer effects with random assignment: results for Dartmouth roommates, Quarterly Journal of Economics, 116, pp. 681-704.

Schultz, T. W. (1961) Investment in human capital, American Economic Review, 51(1), pp. 1-17.

Wößmann, L. and West, M. (2002) Class-size effects in school systems around the world: evidence from between-grade variation in TIMMS. Mimeo (Munich: IFO). 